\title{
Hydrological Variability and Agricultural Drainage Ditch Inorganic Nitrogen Reduction Capacity
}

\section{R. Kröger* and M. M. Holland University of Mississippi M. T. Moore and C. M. Cooper USDA-ARS}

The application of inorganic nitrogen fertilizers on agricultural landscapes has the potential to generate concerns of environmental degradation at fine to coarse scales across the catchment and landscape. Inorganic nitrogen species $\left(\mathrm{NO}_{3}{ }^{-}\right.$, $\mathrm{NO}_{2}{ }^{-}$, and $\mathrm{NH}_{3}$ ) are typically associated with subsurface flow processes; however, surface runoff from rainfall events in no-till agriculture with inorganic surface fertilizers might contribute to downstream eutrophication. Inorganic nitrogen reduction capacity of agricultural drainage ditches under no-till cotton was determined under natural, variable rainfall conditions in northern Mississippi. Monthly grab baseflow samples and stormgenerated flow samples were variably sampled temporally within two experimental farm ditches over 2 yr. Inorganic nitrogen concentrations, in conjunction with Manning's equation and Natural Resources Conservation Service dimensionless hydrographs, provided individual water volumes per storm event and thus maximum effluent and outflow nitrogen loads. Base and stormflow regression results indicate drainage ditches reducing $\mathrm{NO}_{3}{ }^{-}$and $\mathrm{NH}_{3}$ over the length of the ditch for growing and dormant seasons. Overall, maximum storm loads of dissolved inorganic nitrogen (DIN) from the farm over the 2-yr sampling period accounted for $2.2 \%$ of the initial fertilizer application, of which $1.1 \%$ left the ditch $\left(0.84 \mathrm{~kg} \mathrm{ha}^{-1} \mathrm{yr}^{-1}\right)$ (a $57 \%$ ditch reduction of DIN load over 2 yr). Long-term sampling incorporating data on application and loss of fertilizers and farm management will provide critical information for farmers and scientists on the potential of economic gains and downstream ecosystem eutrophication, respectively.

Copyright $\odot 2007$ by the American Society of Agronomy, Crop Science Society of America, and Soil Science Society of America. All rights reserved. No part of this periodical may be reproduced or transmitted in any form or by any means, electronic or mechanical, including photocopying, recording, or any information storage and retrieval system, without permission in writing from the publisher.

Published in J. Environ. Qual. 36:1646-1652 (2007). doi:10.2134/jeq2006.0506

Received 20 Nov. 2006.

*Corresponding author (kroger@olemiss.edu).

(1) ASA, CSSA, SSSA

677 S. Segoe Rd., Madison, WI 53711 USA
$A_{\text {sources of nitrogen }(\mathrm{N}) \text { species to aquatic systems }}^{\text {gricultural activities play a major role as nonpoint }}$ (Carpenter et al., 1998; Jolankai and Rast, 1999). Fertilization with ammonium nitrate $\left(\mathrm{NH}_{4} \mathrm{NO}_{3}\right)$ leads to diffuse nonpointsource pollution, with an environmental concern of increased $\mathrm{N}$ levels at fine scales in local downstream ecosystems and at coarser scales throughout the Lower Mississippi Alluvial Valley. A high inorganic $\mathrm{N}$ load within the Mississippi river stimulates algal growth and eutrophication and ultimately contributes greatly to the hypoxic zones in the Gulf of Mexico (Rabalais et al., 1996; Turner and Rabalais, 2003). Fertilizer additions most often exceed the $\mathrm{N}$ requirements of crops, thus creating a pool of potentially leachable nitrate $\left(\mathrm{NO}_{3}^{-}\right)$(Lowrance, 1992; Prakasa Rao and Puttana, 2000). Using agricultural drainage ditches as primary intercept wetlands could potentially control source inorganic $\mathrm{N}$ loads to downstream aquatic environments, especially in the Mississippi River Basin.

Nitrogen is probably the most complex element to characterize in wetland biogeochemical processes (Keeney, 1973). The dominant aqueous $\mathrm{N}$ species of ammonium $\left(\mathrm{NH}_{4}^{+}\right), \mathrm{NO}_{3}^{-}$, nitrite $\left(\mathrm{NO}_{2}{ }^{-}\right)$, and dissolved organic $\mathrm{N}$ undergo simultaneous complex interactions and transformations of mineralization, immobilization, nitrification, denitrification, and assimilation at variable spatial and temporal scales (Klopatek, 1978; Ryden et al., 1984; Braskerud, 2002). Net N concentrations are a combination of these processes as well as the rate of decomposition and the rate of sedimentation (Keeney, 1973). Nitrogen as a nonpoint source pollutant from crop fields occurs predominantly in the inorganic form $\left(\mathrm{NH}_{3}, \mathrm{NO}_{3}^{-}\right.$, and $\left.\mathrm{NO}_{2}^{-}\right)$. Nitrate fertilizer use has been shown to strongly affect $\mathrm{NO}_{3}{ }^{-}$concentrations in tile drainage (i.e., subsurface) from Iowa (Baker and Johnson, 1981; Thomas et al., 1992), and concentration levels and timing of loss is a function of hydrological variability (Jordan et al., 2003).

Agricultural drainage ditches are integral components of the agricultural landscape and act as major conduits of surface and subsurface flow $\mathrm{N}$ from agricultural lands to receiving waters. Drainage ditches are wetlands that are the forgotten links between agricultural fields and receiving waters (Moore et al., 2001). They possess hydric soils, support a diverse community of hydrophytes, and are subject to the unpredictable changes in soil saturation as a result of hydrological variability.

R. Kröger and M.M. Holland, Dep. of Biology, Univ. of Mississippi, University, MS 38677. M.T. Moore and C.M. Cooper, USDA-ARS, National Sedimentation Lab., Oxford, MS 38655.

Abbreviation: DIN, dissolved inorganic nitrogen. 


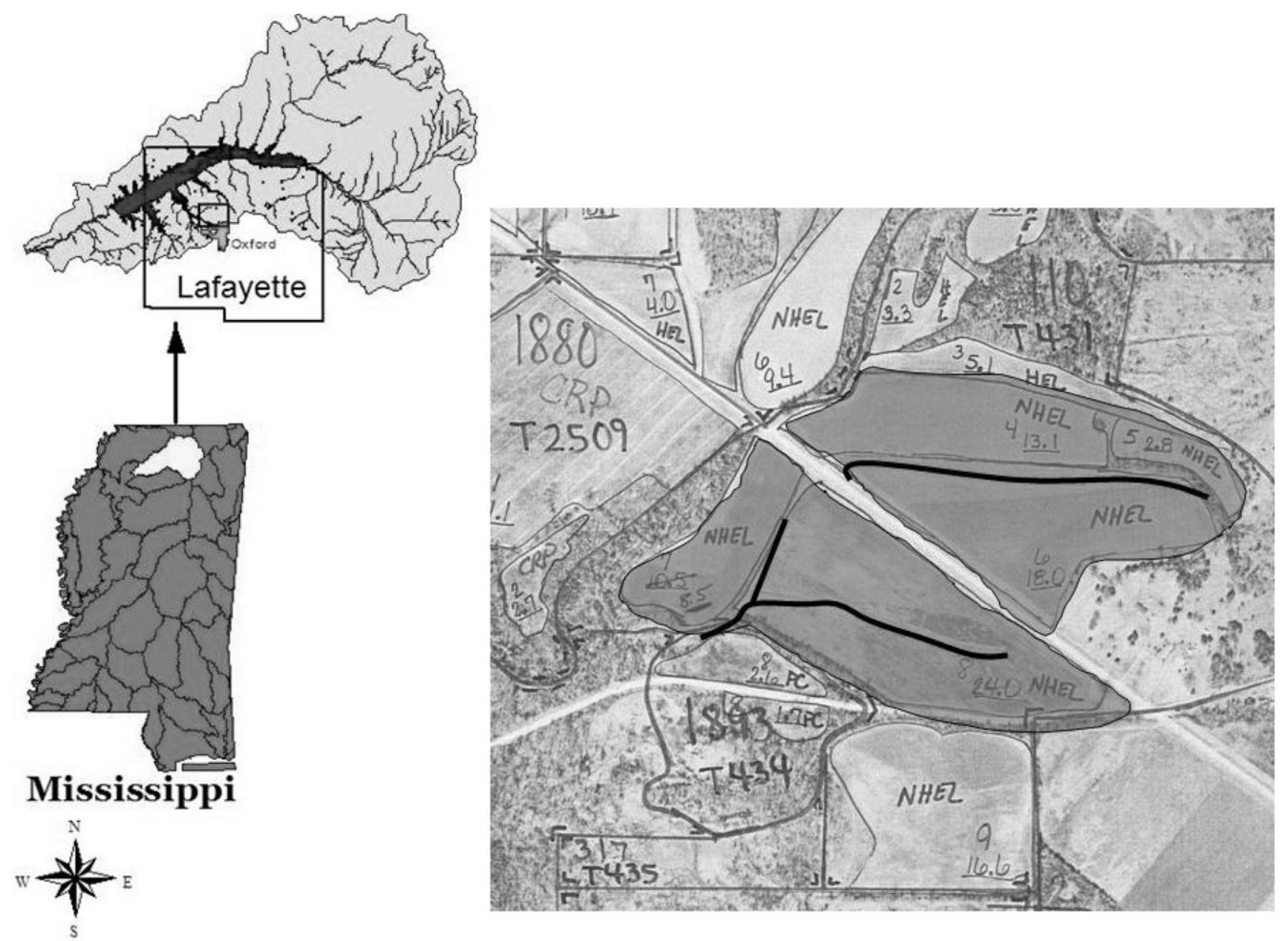

Fig. 1. Study site location within the Little Tallahatchie watershed, Northern Mississippi (MARIS: http://www.maris.state.ms.us [verified 25 July 2007]). Subset is a 2002 aerial photograph of the two field sites in Lafayette County, MS. Bold lines within each farm delineate drainage ditches (aerial photograph compliments of the USDA-NRCS).

Numerous inlet and outlet experiments (Gersberg et al., 1983; Gersberg et al., 1986; Hey et al., 1994; Braskerud, 2002; Szogi et al., 2003) have demonstrated the ability of constructed and natural wetlands in $\mathrm{N}$ mitigation (including $\mathrm{NH}_{3}, \mathrm{NO}_{3}^{-}$, and $\left.\mathrm{NO}_{2}{ }^{-}\right)$. Nitrogen mitigation results from the spatial and temporal separation of oxic and anoxic environments, transforming respective $\mathrm{N}$ species into labile $\mathrm{N}_{2}$ and the immobilization of inorganic usable $\mathrm{N}$ species by macrophyte and micro-organism communities. A lack of information exists on the ability of primary agricultural drainage ditches to mitigate diffuse agricultural runoff. By quantifying $\mathrm{N}$ concentrations and discharge, $\mathrm{N}$ load data provide the quantity of inorganic $\mathrm{N}$ fertilizer that is being transported from farms to downstream ecosystems via surface or subsurface flow and can provide a measure of $\mathrm{N}$ reduction within the drainage ditch.

The primary goal of this study was to quantify the reduction capability of agricultural drainage ditches exposed to elevated $\mathrm{N}$ concentrations in stormflow runoff. Seasonal N concentrations in conjunction with temporal hydrological variability provided the potential to generate inorganic $\mathrm{N}$ loads flowing within the drainage ditch and their subsequent $\mathrm{N}$ load contribution to downstream aquatic environments.

\section{Materials and Methods}

\section{Experimental Design}

This study took place over a 2-yr sampling period (June 2004 through June 2006) in Lafayette County, northern Mississippi (Fig. 1). The experimental design consisted of two agricultural drainage ditches within two field sites (farm 1 and farm 2). Drainage ditches were $400 \mathrm{~m}$ and $460 \mathrm{~m}$ long and had cumulative mean width depth ratios of $7.15 \pm 0.18$ and $6.63 \pm 0.81$, respectively. The ditches were densely vegetated in wetland perennial and annual herbaceous vegetation, typical of the mid-South. Dominant species included Leersia oryzoides L., Sagittaria latifolia Willd., Juncus effuses L., and Echinodorus cordifolius (L.) Griseb. Seven sampling locations were stratified approximately $50 \mathrm{~m}$ apart along each drainage ditch, with each ditch having an additional outlet sampling location. The ditches were located within two fields that had been planted in a summer row crop/winter fallow sequence of no-till cotton since 1995. Cotton was planted in early June and harvested in late October or early November depending on rainfall events. Fields were 13 ha in size; were drained by a primary drainage ditch; and consisted predominantly of Kirkville, Jena, and Ochlockonee soil types (silt loams) (Morris, 1981). Fields were 
planted to within a couple of meters of each drainage ditch without any buffer zones other than the ditch vegetation.

Fertilizer was applied annually in a split application. A pre-plant fertilizer application of $112 \mathrm{~kg} \mathrm{ha}^{-1} \mathrm{NH}_{4} \mathrm{NO}_{3}$ and $56 \mathrm{~kg} \mathrm{ha}^{-1}$ phosphate occurred in late May. An additional $56 \mathrm{~kg} \mathrm{ha}^{-1}$ of $\mathrm{NH}_{4} \mathrm{NO}_{3}$ was applied when the cotton was six nodes high (end of June/early July).

\section{Field Site Sampling Strategy}

Water samples were divided into monthly baseflow samples and storm event samples. Grab baseflow water samples were taken at each sampling location to compare annual and seasonal nutrient concentrations. Stormwater samples were sampled after rainfall events that generated sufficient surface and subsurface runoff to significantly elevate water levels within the drainage ditch to determine nutrient concentrations associated with hydrological variability. Stormwater was sampled variably at each sampling location throughout the growing and dormant seasons of 2004 through 2006. In total, 28 storm events were recorded ( \pm 15 per year). The stormwater sample is considered a conservative measure of nutrient concentrations of the particular storm event because it constitutes an integrated sample of rising, peak, and recession limbs of the storm hydrograph. The stormwater sample was obtained from each sampling location using a 400-ml sampling container attached to a stake in the middle of the ditch, suspended 2 to $3 \mathrm{~cm}$ above the baseflow water level. All water samples were transported back to the lab in an ice chest and analyzed within $48 \mathrm{~h}$.

\section{Hydrological Analysis}

HOBO U20 loggers recorded real-time water level data at 15-min intervals in each experimental ditch. Water depth, a trapezoidal channel, and hydraulic parameters of cross-sectional area, wetted perimeter, and hydraulic radius, in conjunction with Manning's equation for discharge, provided a discharge peak $\left(Q_{p}\right)$ for individual storm events. Hydraulic radius is the cross-sectional area divided by the wetted perimeter. The mean slope of the drainage ditches was 0.004 . Two median end points of Manning's coefficients were estimated for vegetation densities, depending on the season: growing $(n)=0.085$; dormant $(n)=0.025$ (Bakry et al., 1992; Salama and Bakry, 1992; Sellin et al., 2003). A Natural Resources Conservation Service dimensionless unit hydrograph normalized $Q / Q_{p}$ over $T / T_{p}$, where $T_{p}$ is the time to the peak on the storm hydrograph, to generate a total water volume that was transported within specific storm events (Chin, 2000). The Natural Resources Conservation Service dimensionless hydrograph is a flow estimation method that represents the average shape of a large number of unit hydrographs for natural catchments with different characteristics (Chin, 2000). Nutrient concentration and water volume provided a nutrient load for respective storm events. Drainage area was the total area of farm field surrounding each drainage ditch. Each drainage ditch was an isolated primary headwater for their respective receiving waters. Nitrogen loads (kilograms) were evaluated on a per hectare basis. Two loads were calculated: (i) the maximum farm effluent $\mathrm{N}$ load, which represents the highest load attained spatially within the drainage ditch as a result of the combination of surface and subsurface flow processes, and (ii) the outflow
$\mathrm{N}$ load, which represents the actual $\mathrm{N}$ load leaving the drainage ditch at the outflow sampling station before entering receiving waters. Maximum farm effluent and outflow loads are conservative measures of the actual load lost because they are cumulative samples of rising, peak, and recession limbs of the storm hydrograph. Rainfall data were collected at the United States Department of Agriculture facility in Oxford, MS, $5 \mathrm{~km}$ from the field sites.

\section{Nitrogen Analysis}

All water samples from baseflow and stormflow were analyzed for $\mathrm{NO}_{3}{ }^{-}, \mathrm{NO}_{2}{ }^{-}$, and ammonia $\left(\mathrm{NH}_{3}\right)$. Nitrate and $\mathrm{NO}_{2}{ }^{-}$were determined using a Dionex Ion Chromatograph (Dionex, Sunnyvale, CA) (detection limit $\geq 0.5 \mathrm{mg} \mathrm{L}^{-1}$ ) fitted with an anion conductivity detector (Small et al., 1975; Rabin et al., 1993; Dionex, 1997). Ammonia was determined by the standard phenate method (American Public Health Association, 1998). These three nitrogen components were summed to form a total dissolved inorganic nitrogen (DIN) category. Dissolved organic $\mathrm{N}$ was not measured because (i) the farm was fertilized with an inorganic fertilizer and (ii) dissolved organic $\mathrm{N}$ generally provides an insignificant contribution to total $\mathrm{N}$. Total sediment $\mathrm{N}$, which includes inorganic and organic species, was determined by digesting $100 \mathrm{mg}$ of sediment with mercuric-oxide and hydrogen peroxide in a micro-Kjeldahl block (American Public Health Association, 1998) and was analyzing for total sediment $\mathrm{N}$ on a Latchet Quik Chem Auto Analyzer (Pritzlaff, 2003). Rainwater was tested for atmospheric N contributions. Nitrate concentrations from rainwater were below $0.05 \mathrm{mg}$ $\mathrm{NO}_{3}^{-} \mathrm{L}^{-1}$ for the duration of the study.

\section{Statistical Analyses}

This study was performed on an agricultural ditch system that had two replicates (farm 1 and farm 2). A greater, indepth understanding of spatial and temporal fluxes within each ditch was possible with two replicates rather than diffuse sampling of a large replicate of farms, though statistical power was sacrificed. It was recognized that sampling sites within each farm were pseudo-replicates. Baseflow and stormflow data were divided into three categories: (i) annual, consisting of all the months in the year June through May; (ii) growing season, consisting of months April through September; and (iii) dormant season, consisting of the months October through March. Seasonal categories were determined with plant phenology data and monthly fixed-point photographs.

A two-sample, two-tailed Student's test of equal variance was used to compare nutrient loads of growing and dormant seasons of farms between years. Rainfall events, precipitation amounts, nutrient depletion gradients, and nutrient loads within the experimental ditches were correlated with one another using Pearson's correlation and regressions.

\section{Results}

A fine, monthly scale analysis yielded significant individual regression patterns influenced by temporally explicit hydrological events for baseflow (Table 1; Fig. 2). Linear regression and quadratic coefficients were not useful indices for storm- 
Table 1. Correlatory $r$ values of dominant baseflow $\mathrm{N}\left(\mathrm{NO}_{3}{ }^{-}, \mathrm{NH}_{3}\right)$ concentrations and longitudinal distance along farm ditches. Biological significance was determined as $r^{2}$ values explaining more than $25 \%$ of change in nutrient concentrations.

\begin{tabular}{|c|c|c|c|c|}
\hline \multirow[b]{3}{*}{ Season } & \multicolumn{4}{|c|}{ Farms } \\
\hline & \multicolumn{2}{|c|}{$\mathrm{NO}_{3}^{-}$} & \multicolumn{2}{|c|}{$\mathrm{NH}_{3}$} \\
\hline & 2004-05 & 2005-06 & 2004-05 & 2005-06 \\
\hline Jan. & $+0.83 \dagger$ & -0.60 & -0.89 & +0.52 \\
\hline Feb. & +0.79 & -0.53 & N/SS & N/SS \\
\hline Mar. & +0.73 & +0.50 & -0.82 & N/SS \\
\hline Apr. & +0.94 & +0.75 & +0.94 & N/SS \\
\hline May & -0.57 & N/SS & N/SS & -0.60 \\
\hline June & -0.74 & +0.79 & -0.74 & +0.74 \\
\hline July & N/SS & +0.90 & N/SS & N/SS \\
\hline Aug. & N/SS & $-\ddagger$ & N/SS & N/SS \\
\hline Sept. & N/SS & -0.71 & N/SS & -0.75 \\
\hline Oct. & - & - & - & N/SS \\
\hline Nov. & N/SS & -0.79 & -0.86 & -0.53 \\
\hline Dec. & +0.88 & -0.93 & N/SS & -0.85 \\
\hline
\end{tabular}

† A negative value indicates a net decrease in nutrient concentrations; a positive value indicates a net increase in nutrient concentrations; N/SS indicates neither positive nor negative.

$\neq-$ indicates ditch was dry.

flow $\mathrm{N}$ mitigation because concentrations of DIN, $\mathrm{NO}_{3}^{-}$, and $\mathrm{NH}_{3}$ spiked mid-ditch as a result of influent overland surface runoff. Thus, percentage loss or gain measurements determined ditch $\mathrm{N}$ reduction effectiveness (Table 2).

\section{Baseflow and Stormflow Patterns for DIN}

Reduction in ditch baseflow $\mathrm{NO}_{3}{ }^{-}$and $\mathrm{NH}_{3}$ concentrations was variable between years (Table 1; Fig. 2). Over the majority of the growing season (April through September), ditches in 2004 and 2005 were biologically significant in increasing and decreasing
Table 2. Stormflow retention percentages for $\mathrm{NO}_{3}{ }^{-}$and $\mathrm{NH}_{3}$ longitudinally along farm ditches.

\begin{tabular}{|c|c|c|c|c|}
\hline \multirow[b]{3}{*}{ Month } & \multicolumn{4}{|c|}{ Farms } \\
\hline & \multicolumn{2}{|c|}{$\mathrm{NO}_{3}^{-}$} & \multicolumn{2}{|c|}{$\mathrm{NH}_{3}$} \\
\hline & 2004 & 2005 & 2004 & 2005 \\
\hline Jan. & $+1 \dagger$ & -21.5 & -100 & -89 \\
\hline Feb. & +40 & -9 & -88 & -30.5 \\
\hline Mar. & NS‡ & -61.5 & NS & -88.5 \\
\hline Apr. & NS & -92 & NS & -63.5 \\
\hline May & NS & -34.5 & NS & -68.5 \\
\hline June & -59 & -96 & -85 & -60 \\
\hline July & +45 & -100 & -62 & -33.5 \\
\hline Aug. & +25 & NS & -41 & NS \\
\hline Sept. & NS & -70 & NS & -79 \\
\hline Oct. & -1 & NS & -44 & NS \\
\hline Nov. & -10 & -71.5 & -97 & -76.5 \\
\hline Dec. & -25.5 & -56 & -80 & -45.5 \\
\hline
\end{tabular}

† A positive percentage indicates an increase between maximum effluent and outflow nutrient concentrations; a negative percentage indicates a decrease or reduction in concentration.

₹ NS, no storms occurred.

$\mathrm{NO}_{3}{ }^{-}$concentrations (Table 1). In 2004, the lack of significant rainfall postfertilization did not result in the ditches experiencing an increase or decrease in DIN concentrations. The trend, however, was for $\mathrm{NO}_{3}{ }^{-}$concentrations to decrease along the length of the ditches as the growing season progressed (Fig. 2). Marked differences in the ditch reduction patterns of the dormant seasons between years were observed. In 2004, where discharges (Table 3) and rainfall amounts (Table 4) throughout the dormant season (October through March) were high, the ditches' $\mathrm{NO}_{3}{ }^{-}$concentration increased longitudinally along the ditch (Fig. 2). In contrast,

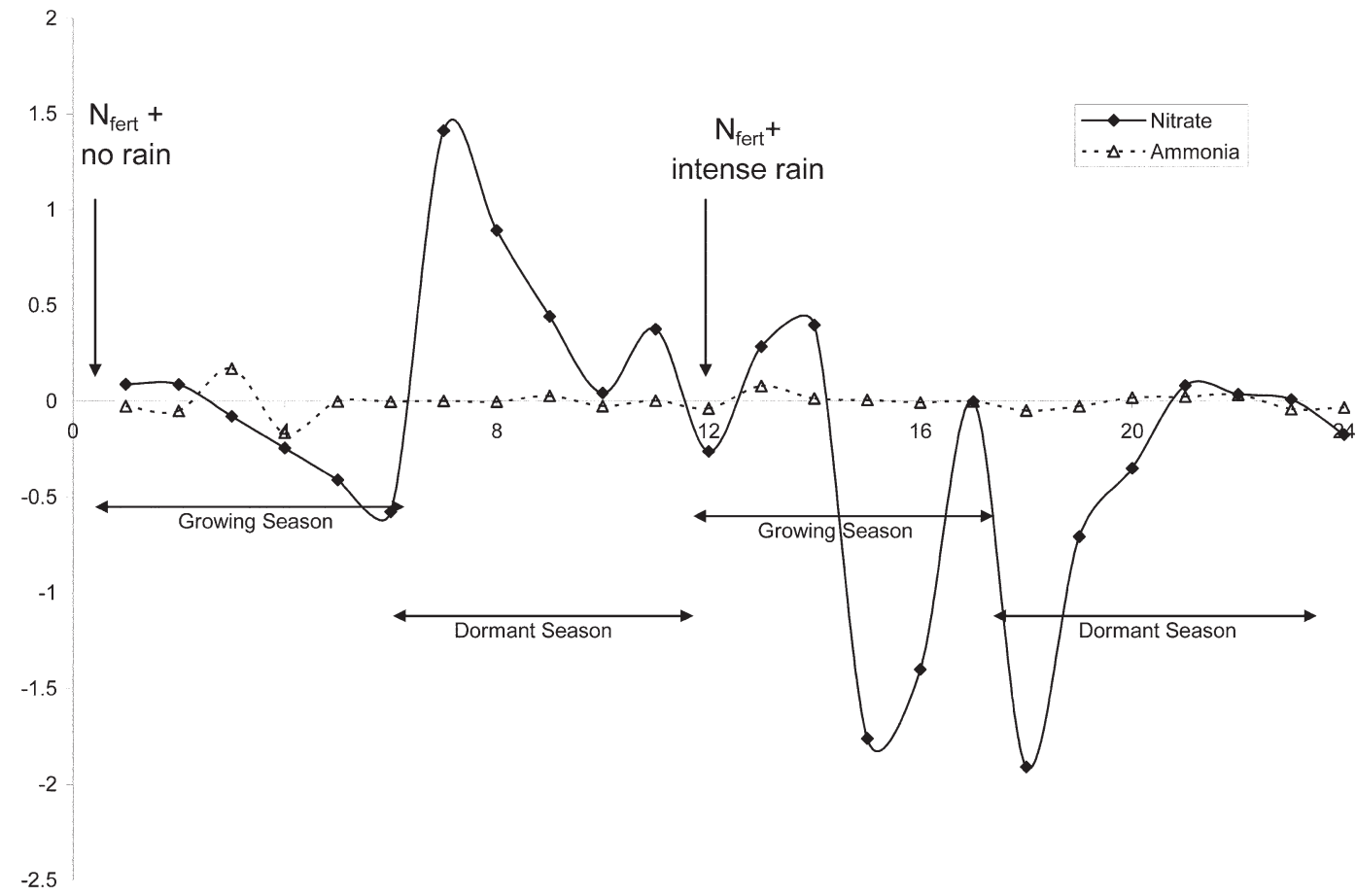

Months

Fig. 2. Change in regression slope lines for baseflow $\mathrm{N}$ concentrations over the 2 -yr study period. Two fertilization events occurred in June/July of 2004 and 2005; growing and dormant season periods are overlaid within the plot. 
Table 3. Growing, dormant, and annual hydrograph characteristics and mean outflow stormflow concentrations for $\mathrm{NO}_{3}$ and $\mathrm{NH}_{3}$. Values are summed and averaged for both farms over 2004 and 2005.

\begin{tabular}{|c|c|c|c|c|c|c|}
\hline \multirow[b]{2}{*}{ Year } & \multirow[b]{2}{*}{ Storm event } & \multirow[b]{2}{*}{ Hydraulic radius } & \multirow[b]{2}{*}{ Max stage } & \multirow[b]{2}{*}{ Average $Q_{p}$} & \multicolumn{2}{|c|}{ Mean nutrient concentrations per ha } \\
\hline & & & & & $\mathrm{NO}_{3}$ & $\mathrm{NH}_{3}$ \\
\hline & & $\mathrm{m} \pm \mathrm{SE}$ & $\mathrm{cm} \pm \mathrm{SE}$ & $\mathrm{m}^{3} \mathrm{~s}^{-1} \pm \mathrm{SE}$ & - & \\
\hline \multirow[t]{3}{*}{ 2004-05 } & growing & $0.21 \pm 0.02$ & $36.3 \pm 5.4$ & $0.0008 \pm 0.0002$ & $0.906 \pm 0.30$ & $0.284 \pm 0.02$ \\
\hline & dormant & $0.30 \pm 0.05$ & $50.9 \pm 11.3$ & $0.011 \pm 0.004$ & $2.35 \pm 0.29$ & $0.137 \pm 0.02$ \\
\hline & annual & $0.26 \pm 0.04$ & $44.9 \pm 6.6$ & $0.006 \pm 0.003$ & $1.81 \pm 0.32$ & $0.189 \pm 0.02$ \\
\hline \multirow[t]{3}{*}{$2005-06$} & growing & $0.29 \pm 0.06$ & $48.9 \pm 10$ & $0.002 \pm 0.001$ & $0.607 \pm 0.21$ & $0.180 \pm 0.02$ \\
\hline & dormant & $0.23 \pm 0.04$ & $39.5 \pm 6.6$ & $0.004 \pm 0.001$ & $0.927 \pm 0.15$ & $0.113 \pm 0.019$ \\
\hline & annual & $0.26 \pm 0.03$ & $43.8 \pm 6$ & $0.003 \pm 0.0008$ & $0.720 \pm 0.20$ & $0.154 \pm 0.02$ \\
\hline
\end{tabular}

in 2005 when water volumes were significantly less (Table 4), the ditches significantly decreased $\mathrm{NO}_{3}{ }^{-}$concentrations (Fig. 2). Ammonia concentrations and regression slopes for 2004 and 2005 were lower than that for $\mathrm{NO}_{3}^{-}$, and for the majority no trend in increasing or decreasing $\mathrm{NH}_{3}$ concentrations occurred (Table 1).

Nitrate stormflow reduction patterns for 2004 were dependent on variations in intense, infrequent storms that caused shifts between increasing or reducing events within and between months (Table 2). These variations in rainfall amounts resulted in variable observed concentrations leaving the ditches over the course of the study (Table 5). There was a distinct difference in $\mathrm{NO}_{3}{ }^{-}$concentrations (Table 5) and percentage reduction of $\mathrm{NO}_{3}{ }^{-}$(Table 2) for the ditches between 2004 and 2005. In 2004, a lack of spring rainfall and scattered rainfall postfertilization resulted in high concentrations of $\mathrm{NO}_{3}{ }^{-}$moving into the ditches with the first significant rains of the growing season (19 July 2004 and 30 Aug. 2004). In 2005, continuous rainfall preand postfertilization decreased and dispersed overall storm event loads within the ditch for $\mathrm{NO}_{3}{ }^{-}$and for $\mathrm{NH}_{3}$ (Table 2). Over the 2004 dormant season, heterogeneity in excessive water volumes, subsurface flows, and significant senescence from nutrient-enriched ditch vegetation resulted in the ditches alternating between reducing or increasing $\mathrm{NO}_{3}{ }^{-}$concentrations longitudinally within the ditches (Table 2). These large rainfall amounts are correlated significantly $(p<0.05)$ with higher $2004 \mathrm{NO}_{3}{ }^{-}$concentrations in stormflows when compared with $2005 \mathrm{NO}_{3}^{-}$concentrations. Over the 2005 dormant season, lower DIN runoff concentrations over the growing season (Tables 3 and 5), coupled with lower water volumes (Table 3 ) in the dormant season, resulted in the ditches reducing $\mathrm{NO}_{3}{ }^{-}$and $\mathrm{NH}_{3}$ (Table 2). Ammo- nia concentrations were low in stormflows throughout 2004 and 2005, with the ditch significantly reducing $\mathrm{NH}_{3}$ concentrations (2005: 62.2\% $\pm 28.7 ; 2004: 76.6 \% \pm 24.7$ ) over both years.

\section{DIN Load Reduction}

Fluxes in maximum farm effluent and outflow inorganic DIN load were directly related to seasonal water volumes between 2004 and 2005 (Tables 3 and 4). Over 2 yr, all but the 2005 growing season (three storm events) showed a decrease in total DIN load $\left(\mathrm{NO}_{3}{ }^{-}+\mathrm{NH}_{3}\right)$ between the maximum farm effluent and the outflow load (Table 3). The exception occurred postfertilization in the 2005 growing season where intense, large stormflows carried significantly $(p=0.042)$ larger mean outflow loads $(0.161 \mathrm{~kg})$ than the mean maximum farm effluent loads $(0.137 \mathrm{~kg}$ ) (Table 4$)$. In 2004 , there was a $61 \%$ annual net reduction of $\mathrm{NO}_{3}^{-}$, whereas in 2005 , the above-mentioned significant storm events significantly $(p<0.05)$ reduced the ditches' overall mitigation of $\mathrm{NO}_{3}{ }^{-}$to $22 \%$. There was no significant difference $(p>0.05)$ between $\mathrm{NH}_{3}$ reduction in 2004 (54\%) and 2005 (64\%). Overall, mean maximum storm loads for 2004 and 2005 combined were $2.2 \%(24.18 \mathrm{~kg}$ or $3.74 \mathrm{~kg} \mathrm{ha}^{-1}$ or $1.87 \mathrm{~kg} \mathrm{ha}^{-1} \mathrm{yr}^{-1}$ ) of the total fertilizer application $\left(168 \mathrm{~kg} \mathrm{ha}^{-1}\right)$. Of this effluent load, $1.1 \%$ left the ditch $(10.38 \mathrm{~kg}$ or $1.67 \mathrm{~kg} \mathrm{ha}^{-1}$ or $\left.0.84 \mathrm{~kg} \mathrm{ha}^{-1} \mathrm{yr}^{-1}\right)$, equaling a mean ditch DIN load reduction of $57 \%$ over $2 \mathrm{yr}$.

\section{Discussion}

\section{Baseflow and Stormflow DIN Variability}

Nitrate, a product of nitrification and dissolution of $\mathrm{NH}_{4} \mathrm{NO}_{3}$, is commonly leached via subsurface pathways, increasing base-

Table 4. Maximum farm effluent and outflow N loads within two drainage ditches during stormflows for 2004 and 2005.

\begin{tabular}{|c|c|c|c|c|c|c|}
\hline \multirow[b]{2}{*}{ Year } & & \multirow{2}{*}{$\begin{array}{c}\text { Total water } \\
\text { volume }\end{array}$} & \multicolumn{2}{|c|}{ Maximum $\mathrm{N}$ effluent load $\dagger$} & \multicolumn{2}{|c|}{ Outflow N load‡ } \\
\hline & & & Mean $\mathrm{NO}_{3} /$ storm event & Mean $\mathrm{NH}_{3} /$ storm event & Mean $\mathrm{NO}_{3}$ /storm event & Mean $\mathrm{NH}_{3} /$ storm event \\
\hline & & $\mathrm{L}$ & & & & \\
\hline \multicolumn{7}{|l|}{ 2004-05 } \\
\hline \multirow{2}{*}{ Growing } & Farm 1 & $108,244.2$ & $0.23 \pm 0.17$ & $0.01 \pm 0.007$ & $0.07 \pm 0.07$ & $0.01 \pm 0.003$ \\
\hline & Farm 2 & $183,383.7$ & $0.04 \pm 0.03$ & $0.01 \pm 0.003$ & $0.01 \pm 0.01$ & $0.002 \pm 0.001$ \\
\hline \multirow[t]{2}{*}{ Dormant } & Farm 1 & $2,159,206$ & $1.2 \pm 0.80$ & $0.05 \pm 0.06$ & $0.51 \pm 0.32$ & $0.01 \pm 0.03$ \\
\hline & Farm 2 & $1,379,103$ & $1.33 \pm 0.88$ & $0.07 \pm 0.11$ & $0.57 \pm 0.33$ & $0.01 \pm 0.06$ \\
\hline \multicolumn{7}{|l|}{ 2005-06 } \\
\hline \multirow[t]{2}{*}{ Growing } & Farm 1 & $420,080.5$ & $0.04 \pm 0.01$ & $0.03 \pm 0.02$ & $0.15 \pm 0.09$ & $0.01 \pm 0.01$ \\
\hline & Farm 2 & $648,233.5$ & $0.23 \pm 0.14$ & $0.03 \pm 0.02$ & $0.17 \pm 0.11$ & $0.01 \pm 0.01$ \\
\hline \multirow[t]{2}{*}{ Dormant } & Farm 1 & $790,132.9$ & $0.10 \pm 0.04$ & $0.03 \pm 0.02$ & $0.04 \pm 0.02$ & $0.02 \pm 0.01$ \\
\hline & Farm 2 & $1,054,238$ & $0.43 \pm 0.27$ & $0.08 \pm 0.07$ & $0.14 \pm 0.07$ & $0.02 \pm 0.02$ \\
\hline
\end{tabular}

† Loads based on Natural Resources Conservation Service dimensionless storm hydrographs and Manning's $n$ coefficients of 0.025 (dormant), 0.085 (growing). Maximum farm effluent is the highest attained load within each respective drainage ditch.

₹ Outflow is the load leaving the ditch and entering receiving waters. 
flow DIN concentrations and loads. Gilliam and Skaggs (1986) described a continuum of $\mathrm{NO}_{3}{ }^{-}$loss from surface drainage to high-intensity subsurface drainage in North Carolina. Nitrate $\mathrm{N}$ losses varied from $3.7 \mathrm{~kg} \mathrm{ha}^{-1} \mathrm{yr}^{-1}$ in surface-drained systems to $15.7 \mathrm{~kg} \mathrm{ha}^{-1} \mathrm{yr}^{-1}$ for medium-intensity subsurface drainage to $32.4 \mathrm{~kg} \mathrm{ha}^{-1} \mathrm{yr}^{-1}$ for high-intensity systems. In this study, agricultural drainage ditches had a maximum DIN farm effluent loss of $1.87 \mathrm{~kg} \mathrm{ha}^{-1} \mathrm{yr}^{-1}$ in stormflow from no-till cotton (Table 4). This loss was half of that described by Gilliam and Skaggs (1986) and was a factor of conservative farm management practices of notill, split fertilizer applications, and reduced subsurface drainage through poorly drained soils. Baseflows, a sum of subsurface processes, had low relative mean $\mathrm{NO}_{3}{ }^{-}$concentrations $(2.5 \mathrm{mg} \mathrm{N} / \mathrm{L} \pm$ 0.6). Low $\mathrm{NO}_{3}{ }^{-}$concentrations and small DIN loads losses from initial fertilizer applications could be attributed to (i) adsorption of $\mathrm{NH}_{4}^{+}$anions to sediments and soil particles, (ii) assimilation and sequestration by harvested crops and drainage ditch vegetation, and (iii) denitrification in saturated farm soil conditions and within the drainage ditch. Plant assimilation, particularly for ditch vegetation, contributes to dormant season fluxes, with assimilated nutrients being released back into the ditch system through senescence. The proportion of nutrients translocated to below-ground structures was unknown; however, high-dormant-season ditch $\mathrm{NO}_{3}{ }^{-}$concentrations and the ditch increasing $\mathrm{NO}_{3}{ }^{-}$concentrations over the 2004 dormant season suggested that plant senescence played a role in $\mathrm{N}$ losses. The lack of overland surface runoff in the 2004 growing season and consequently slow saturated baseflow conditions provided a large hydraulic retention time for plants to assimilate large concentrations of $\mathrm{N}$ into above-ground tissues. Subsequently, above-ground senescence paired with large water volumes and discharges in the dormant season of 2004 initiated more vigorous tissue degradation and large $\mathrm{NO}_{3}{ }^{-}$loads within the drainage ditches (Table 3). A large DIN load reduced the capacity of $\mathrm{N}$ mitigation (Table 4). This is also evident in stormflows (January and February) where large stormwater volumes, in conjunction with inorganic $\mathrm{N}$ that had not leached postfertilization, moved with overland runoff and overloaded the ditch, increasing concentrations of inorganic $\mathrm{N}$ (Table 5). The lack of temperature-dependent aspects of the $\mathrm{N}$ cycle, such as microbial immobilization and denitrification, could have also exacerbated the lack of $\mathrm{N}$ reduction within the ditches over the 2004 dormant season. In comparison to 2005, the 2004 dormant season had a more consistent water volume and annual discharge rate. This consistency temporally homogenized $\mathrm{NO}_{3}{ }^{-}$loads within the ditches and caused the ditches in baseflow and stormflow conditions to reduce inorganic $\mathrm{N}$ concentrations and loads.

\section{Factors Influencing Variability in DIN in Surface-Flow Pathways}

Farming practices, hydrology, and the temporal balance between storm events and soil saturation defines an interesting point to help our understanding of the reasons for inorganic $\mathrm{N}$ flow pathways. Forty-eight percent of the precipitation that fell as storm events within this study initiated overland surface runoff. This percentage was variable between years and seasons. For ex-
Table 5. Observed storm outflow concentrations for $\mathrm{NO}_{3}{ }^{-}$and $\mathrm{NH}_{3}$ within two drainage ditches over a 2-yr study period.

\begin{tabular}{|c|c|c|c|c|}
\hline \multirow[b]{3}{*}{ Month } & \multicolumn{4}{|c|}{ Farms } \\
\hline & \multicolumn{2}{|c|}{$\mathrm{NO}_{3}^{-}$} & \multicolumn{2}{|c|}{$\mathrm{NH}_{3}$} \\
\hline & 2004 & 2005 & 2004 & 2005 \\
\hline & \multicolumn{4}{|c|}{$\mathrm{mg} \mathrm{L}^{-1} \pm \mathrm{SE}$} \\
\hline Jan. & $+0.92 \pm 0 \dagger$ & $-0.83 \pm 1.1$ & $0 \pm 0$ & $-0.23 \pm 0.20$ \\
\hline Feb. & $+3.52 \pm 2.98$ & $-0.7 \pm 1.0$ & $-0.04 \pm 0.01$ & $-0.15 \pm 0.04$ \\
\hline Mar. & NS‡ & $0 \pm 0$ & NS & $-0.12 \pm 0.04$ \\
\hline Apr. & NS & $-0.02 \pm 0.02$ & NS & $-0.01 \pm 0.009$ \\
\hline May & NS & $-1.7 \pm 0.72$ & NS & $-0.05 \pm 0.02$ \\
\hline June & $-1.09 \pm 0$ & $-2.2 \pm 3.7$ & $-0.02 \pm 0.03$ & $-0.08 \pm 0.11$ \\
\hline July & $+0.89 \pm 0.66$ & $0 \pm 0$ & $-0.10 \pm 0.04$ & $-0.29 \pm 0.23$ \\
\hline Aug. & $+0.86 \pm 1.6$ & NS & $-0.24 \pm 0.17$ & NS \\
\hline Sept. & NS & $-1.26 \pm 1.7$ & NS & $-0.05 \pm 0.04$ \\
\hline Oct. & $-0.035 \pm 0.05$ & NS & $-0.2 \pm 0.02$ & NS \\
\hline Nov. & $-4.2 \pm 1.1$ & $-0.1 \pm 0.18$ & $-0.01 \pm 0.002$ & $-0.03 \pm 0.04$ \\
\hline Dec. & $-1.7 \pm 0.24$ & $-1.16 \pm 1.14$ & $-0.02 \pm 0.03$ & $-0.06 \pm 0.01$ \\
\hline \multicolumn{5}{|c|}{$\begin{array}{l}\text { † A positive value indicates outflow nutrient concentrations were } \\
\text { highest within the ditch; a negative percentage indicates a decrease or } \\
\text { reduction in concentration. }\end{array}$} \\
\hline$\neq N S$, no & torms occurred. & & & \\
\hline
\end{tabular}

ample, runoff events were more likely to generate runoff resulting in higher inorganic $\mathrm{N}$ loads over the 2004 dormant season than over the 2005 dormant season. The lack of rainfall and leaching in the 2004 growing season could also have contributed to high $\mathrm{NO}_{3}{ }^{-}$runoff concentrations and loads over the subsequent dormant season. Nitrate loads were significantly lower in the 2005 dormant season, with consistent rainfall patterns within the previous growing season. Gambrell et al. (1975) suggested that in the humid southeast, evapotranspiration and lack of rainfall limits $\mathrm{N}$ leaching in summer. However, on poorly drained soils, residual $\mathrm{NO}_{3}{ }^{-}$may be removed from the root depth by leaching and surface runoff through rainfall over the winter and spring, increasing $\mathrm{NO}_{3}{ }^{-}$loads in surface ditches in winter.

\section{DIN Load Reduction within Drainage Ditches}

The total effluent annual loss of DIN on farms under no-till cotton demonstrated that as little as $2.5 \%$ of the initial fertilizer was transported into the drainage ditch through runoff and storm events (Table 4). Runoff losses of $\mathrm{NO}_{3}{ }^{-}$in Maryland were similarly very small in comparison to yearly applications of $\mathrm{N}$ fertilizers (Angle et al., 1984). Sharpley et al. (1983) observed maximum concentrations of $\mathrm{NO}_{3}{ }^{-}$and $\mathrm{NH}_{3}$ in surface runoff post-urea application on permanent pasture in New Zealand. Furthermore, the study reported close to $7 \%$ loss of DIN of the initial fertilizer application. Jacobs and Gilliam (1985) reported 10 to $55 \mathrm{~kg} \mathrm{ha}^{-1} \mathrm{yr}^{-1}$ of $\mathrm{NO}_{3}{ }^{-}$loss from farms under subsurface drainage, whereas surface-drained farms lost only 6 to $12 \mathrm{~kg} \mathrm{ha}^{-1} \mathrm{yr}^{-1}$ (8.2\% loss). In this study, drainage ditches reduced the initial $2.5 \%$ DIN load to less than $1.5 \%$, which is a $57 \%$ reduction in DIN over the 2-yr study period (Table 3). Although there was a disparity between 2004 and 2005 ditch DIN reduction capacities, there were no significant differences in the $\mathrm{NH}_{3}$ mitigation capacity of the ditches between 2004 and 2005. Ammonia is an N species that is adsorbed to sediment and thus less influenced by subsurface leaching and surface flows postfertilization. In 2004, the drainage ditches reduced $61 \%$ of the $\mathrm{NO}_{3}^{-}$; however, the percentage dropped to $22 \%$ in 2005 . 
Intense storm and surface runoff events postfertilization in 2005 transported the highly mobile $\mathrm{NO}_{3}{ }^{-}$anion into the ditch at higher concentrations, thus overloading the reduction capacity and reducing the ditches' annual effectiveness.

Dissolved inorganic $\mathrm{N}$ and $\mathrm{NO}_{3}{ }^{-}$outflow loads could be substantially reduced in winter by using controlled drainage. Controlled drainage significantly improves hydraulic retention time and provides microbes a greater ability to transform and immobilize DIN. Controlled drainage can be achieved with low-grade weirs strategically placed within the ditch or a slotted board outlet to control water outflow height during the dormant or growing seasons.

\section{Conclusions}

No-till farming practices without subsurface tile drainage elevate the water table, reduce subsurface flows, and increase denitrification rates in lower soil profiles. A concomitant increase in surface runoff elevates other pollutants but is of little consequence for $\mathrm{NO}_{3}{ }^{-}$and DIN, which readily leach subsurfacely. Dissolved inorganic $\mathrm{N}$ that entered drainage ditches via surface and subsurface processes was less than half of the original effluent DIN load. How drainage ditches reduce the DIN load could be hypothesized but is empirically unknown. Denitrification, plant assimilation and translocation, $\mathrm{NH}_{3}$ volatilization, a complex $\mathrm{N}$ cycle of mineralization, transformation between dry and saturated ditch conditions, and potential leaching to groundwater are processes warranting further study. Understanding these complex interactions, as driven by hydrology, will yield information as to how to improve the ditches' capacity to reduce nonpoint source loads to receiving waters.

\section{Acknowledgments}

The authors thank the cooperation of a willing anonymous farmer; Joe Huggins of Goose Ranch Hunting Club; Landon Lee for hours spent in the field setting up field stations, sampling, and analysis; and Mackie Riddle at the NRCS, Oxford MS for help in initial field site evaluation. We acknowledge funding through the cooperative agreement of the USDA-ARS No. 586408-1-095 to the University of Mississippi and 2004/2005 Ralph Powe Award through the UMFS.

\section{References}

American Public Health Association. 1998. Standard methods for the examination of water and wastewater. 20th ed. American Public Health Assoc., Washington, DC.

Angle, J.S., G. McClung, M.S. McIntosh, P.M. Thomas, and D.C. Wolf. 1984. Nutrient losses in runoff from conventional and no-till corn watersheds. J. Environ. Qual. 13:431-435.

Baker, J.L., and H.P. Johnson. 1981. Nitrate-nitrogen in tile drainage as affected by fertilization. J. Environ. Qual. 10:519-522.

Bakry, M.F., T.K. Gates, and A.F. Khatab. 1992. Field-measured hydraulic resistance characteristics in vegetation-infested canals. J. Irrig. Drain. Eng. 118:256-274.

Braskerud, B.C. 2002. Factors affecting nitrogen retention in small constructed wetlands treating agricultural non-point source polution. Ecol. Eng. 18:351-370.

Carpenter, S., N.F. Caraco, D.L. Correl, R.W. Howarth, A.N. Sharpley, and V.H. Smith. 1998. Nonpoint pollution of surface waters with phosphorus and nitrogen. Issues Ecol. 3:1-12.

Chin, D.A. 2000. Water resources engineering. Prentice Hall, New Jersey.

Dionex. 1997. DX-120 Ion Chromatograph User’s Guide. Document No. 031183 revision 02, March 1997. Dionex Corp., Sunnyvale, CA.

Gambrell, R.P., J.W. Gilliam, and S.B. Weed. 1975. Nitrogen losses from soils of the North Carolina Coastal plain. J. Environ. Qual. 4:317-323.

Gersberg, R.M., B.V. Elkins, and C.R. Goldman. 1983. Nitrogen removal in artificial wetlands. Water Res. 17:1009-1014.

Gersberg, R.M., B.V. Elkins, S.R. Lyon, and C.R. Goldman. 1986. Role of aquatic plants in wastewater treatment by artificial wetlands. Water Res. 20:363-368.

Gilliam, J.W., and R.W. Skaggs. 1986. Controlled agricultural drainage to maintain water quality. J. Irrig. Drain. Eng. 112:254-263.

Hey, D.L., A.L. Kenimer, and K.R. Barrett. 1994. Water quality improvement by four experimental wetlands. Ecol. Eng. 3:381-397.

Jacobs, T.C., and J.W. Gilliam. 1985. Riparian losses of nitrate from agricultural drainage waters. J. Environ. Qual. 14:472-478.

Jolankai, G., and W. Rast. 1999. The hydrologic cycle and factors affecting the generation, transport and transformation of non-point source pollutants. p. 41-72. In J.A. Thornton et al. (ed.) Assessment and control of nonpoint source pollution of aquatic ecosystems: A practical approach. UNESCO \& Parthenon Publ. Group, New York.

Jordan, T.E., D.F. Whigham, K. Hofmockel, and M.A. Pittek. 2003. Nutrient and sediment removal by a restored wetland receiving agricultural runoff. J. Environ. Qual. 32:1534-1547.

Keeney, D.R. 1973. The nitrogen cycle in sediment-water systems. J. Environ. Qual. 2:15-29.

Klopatek, J.M. 1978. Nutrient dynamics of freshwater riverine marshes and the role of emergent macrophytes. p. 195-216. In R.E. Good et al. (ed.) Freshwater wetlands: Ecological processes and management potential. Academic Press Inc., New York.

Lowrance, R. 1992. Nitrogen outputs from a field-size agricultural watershed. J. Environ. Qual. 21:602-607.

Moore, M.T., E.R. Bennett, C.M. Cooper, S. Smith, Jr., F.D. Shields, C.D. Milam, and J.L. Farris. 2001. Transport and fate of atrazine and lambda-cyhalothrin in an agricultural drainage ditch in the Mississippi Delta, USA. Agric. Ecosyst. Environ. 87:309-314.

Morris, W.M. 1981. Soil survey of Lafayette County, Mississippi. USDA, Soil Conservation Service and Forest Service, Washington, DC.

Prakasa Rao, E.V.S., and K. Puttana. 2000. Nitrates, agriculture, and environment. Curr. Sci. 79:1163-1168.

Pritzlaff, D. 2003. Determination of nitrate/nitrite in surface and wastewaters by flow injection analysis. QuikChem Method 10-107-04-1-C. Lachat Instruments, Loveland, CO.

Rabalais, N.N., G.A. Turner, Q. Dortch, W.J. Wiseman, Jr., and B.K.S. Gupta. 1996. Nutrient changes in the Mississippi River and system responses on the adjacent continental shelf. Estuaries 19:386-407.

Rabin, S., J. Stillian, V. Barreto, K. Friedman, and M. Toofan. 1993. New membrane-based electrolytic suppressor device for suppressed conductivity detection in ion chromatography. J. Chromatogr. 640:97-109.

Ryden, J.C., P.R. Ball, and E.A. Garwood. 1984. Nitrate leaching from grassland. Nature 311:50-53.

Salama, M.M., and M.F. Bakry. 1992. Design of earthen vegetated open channels. Water Resour. Manage. 6:149-159.

Sellin, R.H.J., T.B. Bryant, and J.H. Loveless. 2003. An improved method for roughening floodplains on physical river models. J. Hydraul. Res. 41:3-14.

Sharpley, A.N., J.K. Syers, and R.W. Tillman. 1983. Transport of ammonium- and nitrate-nitrogen in surface runoff from pasture as influenced by urea application. Water Air Soil Pollut. 20:425-430.

Small, H., T.S. Stevens, and W.C. Bauman. 1975. Novel ion exchange chromatographic method using conductimetric detection. Anal. Chem. 47:1801-1809.

Szogi, A.A., P.G. Hunt, and F.J. Humenik. 2003. Nitrogen distribution in soils of constructed wetlands treating lagoon wastewater. Soil Sci. Soc. Am. J. 67:1943-1951.

Thomas, G.W., G.R. Haszler, and J.D. Crutchfield. 1992. Nitrate-nitrogen and phosphate-phosphorus in seven Kentucky streams draining small agricultural watersheds: Eighteen years later. J. Environ. Qual. 21:147-150.

Turner, R.E., and N.N. Rabalais. 2003. Linking landscape and water quality in the Mississippi River Basin for 200 years. Bioscience 53:563-572. 